\title{
Review
}

\section{The Optimal Dietary Fat to Carbohydrate Ratio to Prevent Obesity in the Japanese Population: A Review of the Epidemiological, Physiological and Molecular Evidence}

\author{
Osamu EZAKI \\ Department of Nutritional Science, National Institute of Health and Nutrition, 1-23-1 Toyama, \\ Shinjuku-ku, Tokyo 162-8636, Japan
}

(Received July 13, 2011)

\begin{abstract}
Summary The prevention of obesity, which leads to diabetes and other diseases, is a major concern for public health. There might be an optimal dietary fat to carbohydrate ratio for prevention and treatment of obesity. According to the Japanese Dietary Reference Intakes (RDA) for 2010, the optimal fat intake is $20-30 \%$ of energy for ages 1-29 y and 20$25 \%$ for ages $30 \mathrm{y}$ and over. Upper boundary values of this recommendation were the median of the percentage of energy from dietary fat in Japanese. In a systematic review to estimate the optimal dietary fat to carbohydrate ratio, it was found that obese subjects with hyperinsulinemia (or insulin resistance) lost more weight on a mild low-carbohydrate (LC) (or low-glycemic load diet; $40 \%$ carbohydrate, $30-35 \%$ fat) than on a low-fat (LF) diet (55$60 \%$ carbohydrate, $20 \%$ fat), whereas those without hyperinsulinemia showed the opposite. In non-obese primarily insulin-sensitive subjects, decreasing fat rather than carbohydrate intake is generally more effective to prevent obesity. Physiological and molecular evidence supports this conclusion. Increased carbohydrate intake, especially in high-glycemic food, leads to postprandial hyperglycemia and hyperinsulinemia, which are exaggerated in obese insulin-resistant subjects. Even in an insulin-resistant state, insulin is able to stimulate fatty acid synthesis in liver, activate lipoprotein lipase, and prevent lipolysis in adipose tissues, which all facilitate adipose tissue enlargement. Optimal dietary fat to carbohydrate ratio may differ in populations depending on their prevalence for obesity. Because the prevalence of overweight/obesity in Japanese is low, a LF diet is recommended in the general population.
\end{abstract}

Key Words low-carbohydrate diet, low-fat diet, RDA, insulin resistance, obesity

Obesity in the United States and in much of the westernized world has increased dramatically over the past several decades: $64.5 \%$ of adults in the United States are overweight (body mass index $[\mathrm{BMI}] \geq 25 \mathrm{~kg} / \mathrm{m}^{2}$ and $\left.<30 \mathrm{~kg} / \mathrm{m}^{2}\right)$ or obese $\left(\mathrm{BMI} \geq 30 \mathrm{~kg} / \mathrm{m}^{2}\right)$ (1). Overweight/obesity $\left(\mathrm{BMI} \geq 25 \mathrm{~kg} / \mathrm{m}^{2}\right)$ was the most important predictor of diabetes. In the Nurses' Health Study, during $16 \mathrm{y}$ of follow-up, 3,300 new cases of type 2 diabetes were observed in the baseline population of 84,941 female nurses. The relative risk of diabetes was 38.8 for women with a BMI of $35.0 \mathrm{~kg} / \mathrm{m}^{2}$ or higher, 20.1 for women with BMI of 30.0 to $34.5 \mathrm{~kg} / \mathrm{m}^{2}$, and 7.59 for women with BMI of 25.0 to $29.9 \mathrm{~kg} / \mathrm{m}^{2}$, as compared with women who had a BMI of less than $23.0 \mathrm{~kg} / \mathrm{m}^{2}(2)$.

In Japan, the prevalence of overweight/obesity $\left(\mathrm{BMI} \geq 25 \mathrm{~kg} / \mathrm{m}^{2}\right)$ in adults is very low compared with the United States: $30.4 \%$ in men and $20.2 \%$ in women in 2007, according to Japanese cross-sectional nationwide surveys (3). However, a strong positive association between baseline BMI and the incidence of diabetes in

E-mail: ezaki@nih.go.jp the follow-up period was observed similar to that in the United States. In a Japanese cohort of healthy men $(n=16,829)$ and women $(n=8,370)$ followed for $7.4 \mathrm{y}$, new cases of diabetes were documented in 869 men and 224 women (4). The relative risk of diabetes was 5.55 for men with a BMI of 25.2 to 26.3 , compared with men who had a BMI of 15.0 to 19.7 , and the relative risk of diabetes was 5.70 for women with a BMI of 24.4 to 25.9 , compared with women who had a BMI of 14.9 to 19.1. Therefore, in Japan also, the prevention of overweight/obese subjects is a major public issue.

The role of dietary fat and carbohydrate in the obesity epidemic has been a hotly debated topic for decades and remains unresolved. To reduce the incidence of obesity in general populations, public statements on optimal ratios of dietary fat to carbohydrate have been issued. Health organizations have recommended diets that are low in total and saturated fat and high in carbohydrates obtained from vegetables, fruits, and whole grains or fiber-rich foods (5-7). Dietary guidelines for Americans published in 2005 emphasized the importance of the amount of energy consumed rather than the proportions of protein, fat, and carbohydrate in the diet, pro- 
vided that the macronutrients are within the AMDR, the acceptable macronutrient distribution range: 10$35 \%$ of energy from protein, 45-65\% from carbohydrate, and 20-35\% from fat (8). Dietary reference intakes for Japanese issued by the Ministry of Health, Labour, and Welfare in 2010 indicated that optimal fat intake is $20-30 \%$ for ages $1-29 \mathrm{y}$ and $20-25 \%$ for ages $30 \mathrm{y}$ and over. Upper boundary values of this recommendation were a median of the percentage of energy from dietary fat in Japanese, a recommendation that most Japanese are able to follow.

The present review was conducted to determine the optimal dietary fat to carbohydrate ratio to prevent obesity in the Japanese population. As a result, it was suggested that a mild low-carbohydrate (LC) diet was effective in reducing body weight in obese subjects with hyperinsulinemia (or insulin resistance), whereas a low-fat (LF) diet favored prevention of obesity in nonobese subjects or treatment of obese subjects without hyperinsulinemia. In addition, to elucidate the molecular mechanisms of obesity in response to a carbohydrate-rich diet, several aspects of insulin actions, namely lipogenesis in the liver, activation of lipoprotein lipase (LPL), and lipolysis under insulin-resistance state were also reviewed.

\section{Methods of Review and Definitions}

Selection of publications of epidemiological studies. For epidemiological studies, key words "(Diet, Fat-Restricted [MESH]) AND (dietary OR intake OR consumption) AND ((randomized controlled trial [PTYP] OR random [WORD]) OR (cohort studies [MESH] OR risk [MESH] OR (odds [WORD] AND ratio [WORD]) OR (relative [WORD] AND risk [WORD]) OR case control [WORD] OR case-control studies [MESH]))" with a limitation of "humans" were used in PubMed to select all publications through June 1, $2011(n=1,004)$, initially to review the effects of dietary fat on mortality and mobility reported therein. From these publications, those related to changes in body weight were selected and reviewed. Other important topics, such as the effects of dietary fat subtypes, i.e., saturated, mono-unsaturated, $n-6$, and $n-3$ fatty acids, on obesity, are not discussed in this review. Because several reviews and meta-analyses have been published since the original search date, publications that appeared after this date are presented in this study with comments relating their findings to those of the previous reviews and meta-analyses. To show a visual representation of the results of the review, findings from representative publications are presented here in figures.

Current body weight is the result of the accumulated daily balance of energy intake and expenditure over previous days. Therefore, the causes of obesity are multifactorial, including such factors as physical activity level, energy intake, and food availability. It is difficult to assess these factors, and there are strong limitations to examining the effects of dietary macronutrients on obesity in cross-sectional and prospective studies (confounding factors may not be measured adequately). For this reason, carefully conducted intervention studies in which dietary fat to carbohydrate ratios were changed were mostly selected for this review.

Selection of publications of physiological and molecular studies. In a review of the mechanism of lipogenic action of insulin (covered later in this review), key words "insulin AND obesity AND ((lipogenesis AND liver) OR LPL OR (lipolysis and adipose tissues))" were used initially in PubMed to select appropriate publications, including reviews. Additional publications, which were necessary to describe the effects of insulin in an insulin-resistance state, were included from citations obtained from review articles and personal reference lists.

Definitions of LF and LC diets. The term LF diet is used relative to that of a high-fat diet in the literature; therefore, the absolute amounts of fat were diverse. In general, a high-fat diet means fat intake provides more than $30 \%$ of energy and a LF diet means less than 30\%. The LC diet has been used in two different types of diet: a very LC diet (ketogenic diet) and a mild LC diet (lowglycemic load diet). Glycemic load is the mathematical product of glycemic index and carbohydrate amount. In the ketogenic diet, carbohydrate intake is less than $40 \mathrm{~g} / \mathrm{d}$ (9), whereas in the low-glycemic load diet, the total amount of carbohydrate is decreased by $10-20 \%$ of energy, and foods containing carbohydrate with lower glycemic index were used. In Japanese, median intake of energy in adults was $1,856 \mathrm{kcal} / \mathrm{d}$, and median intakes of carbohydrate, fat, and protein were $258 \mathrm{~g} / \mathrm{d}$ ( $56 \%$ of energy), $51 \mathrm{~g} / \mathrm{d}(24.8 \%)$, and $68 \mathrm{~g} / \mathrm{d}$ (15\%), respectively, according to The National Health and Nutrition Survey in Japan, 2007 (3). In this review, these two types of LC diets are reviewed separately.

\section{Results and Discussion}

A LF diet prevents obesity in general populations

In a meta-analysis of general populations under freeliving conditions, weight loss was positively and independently associated with a reduction in the percentage of energy as fat $(0.37 \mathrm{~kg} / \%, p<0.005)(10)$. Another meta-analysis of intervention studies also supports this conclusion (11). For every 1\% decrease in energy from fat, there was a $0.28-\mathrm{kg}$ decrease in body weight.

A large randomized intervention trial including 48,835 post-menopausal women in the United States (The Women's Health Initiative Dietary Modification Trial) also supports a LF diet for the prevention of obesity (12). This intervention included group and individual sessions to promote a decrease in fat intake and did not include weight loss or energy restriction goals. Energy from fat was decreased from $38.8 \%$ to $29.8 \%$ in the intervention group, whereas there was no alteration of fat intake in the control group (from $38.8 \%$ to $38.1 \%$ ). Concomitantly, energy from carbohydrate was increased from $44.5 \%$ to $52.7 \%$ in the intervention group, whereas there was no alteration of carbohydrate intake in the control group (from $44.5 \%$ to $44.7 \%$ ). Women in the intervention group lost weight in the first year and maintained a lower weight than the control 

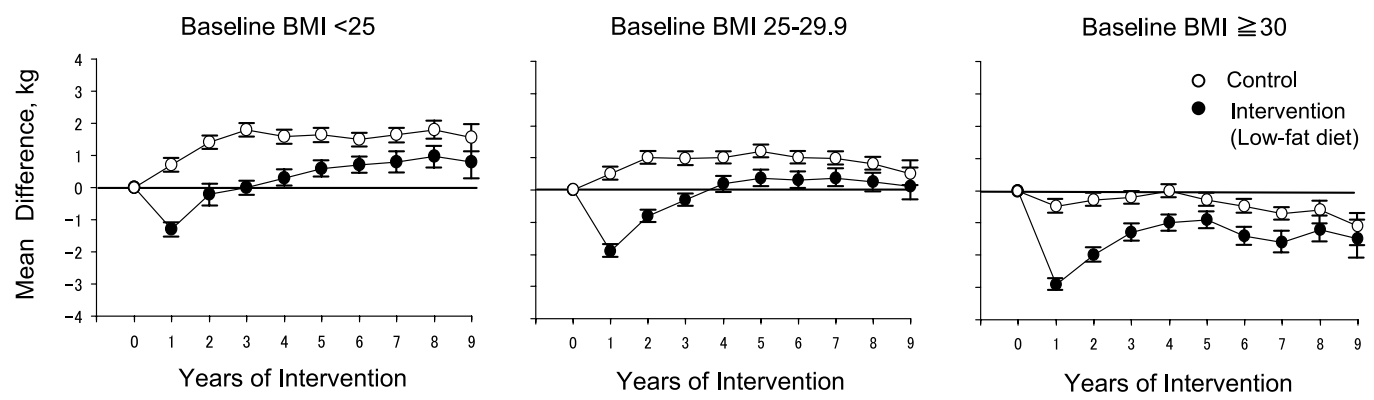

Fig. 1. Differences in body weight by body mass index (BMI) at screening in response to a low-fat (LF) diet. A large randomized intervention trial including 48,835 post-menopausal women during an average $7.5 \mathrm{y}$ of follow-up supports a LF diet (energy from fat decreased from $38.8 \%$ to $29.8 \%$ ) but not energy intake for the prevention of obesity. Women in the intervention groups lost weight in the first year and maintained lower weight than did women in the control groups. No tendency toward weight gain was observed in the intervention groups, whereas body weights in the control groups gradually increased. Error bars indicate $95 \%$ confidence intervals. Patient numbers at baseline for the intervention and control

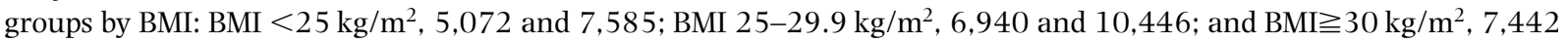
and 11,126, respectively. Reproduced with permission (12).

women over an average $7.5 \mathrm{y}$ of follow-up (Fig. 1). No tendency toward weight gain was observed in the intervention group, whereas body weights in the control group gradually increased. In both groups, weight loss was greatest among women who decreased their percentage of energy from fat. Weight loss in response to fat reduction was also slightly greater in subjects with a baseline BMI of $<25 \mathrm{~kg} / \mathrm{m}^{2}$.

Several mechanisms for body fat increase in response to a high-fat intake have been proposed $(13,14)$. Fat is the most energy-dense of the macronutrients and is palatable. Fat produces less of a thermogenic effect than does carbohydrate $(15,16)$, and fat intake is not regulated, whereas carbohydrate intake is regulated for combustion of carbohydrate substrates (17). A prompt increase in glucose oxidation occurs after ingestion of carbohydrate-containing meals, whereas fat oxidation is reduced after food consumption, even when meals provide substantial amounts of fat (18). These findings indicate that when energy intake is not intentionally restricted, a LF diet prevents body weight increase in the general population.

A very LC diet (ketogenic diet) decreases body weight in obese subjects

Intervention studies to compare the efficacy of LF and very LC diets to reduce body weight in obese subjects have been conducted and summarized in several metaanalyses (19-22). All analyses revealed that a very LC diet is more effective than a LF diet in reducing body weight in obese subjects. In a recent meta-analysis performed by Hession et al., studies comparing the weight loss effects of a very LC diet (less than $60 \mathrm{~g} / \mathrm{d}$ carbohydrate without intentional energy restriction) against a LF diet with energy restriction (less than 30\% fat with $600 \mathrm{kcal} / \mathrm{d}$ energy restriction) of more than 6 mo were included (21). Among 9 studies analyzed $(n=690$ in total), 6 studies (23-28) showed greater reduction in body weight by LC diet than by LF diet, whereas 3 studies (29-31) reported no differences between LC and LF diets in the decrease of body weight when measured at 6 mo of intervention.
However, several adverse effects were observed in a very LC diet. A meta-analysis showed an increase in LDL cholesterol (22). Increased blood ketone productions showed unfavorable effects, such as hyperuricemia and orthostatic hypotension (32). Recently, even under energy restricted conditions, it was reported that a very LC diet (60\% fat/5\% carbohydrate) for $6 \mathrm{wk}$ (33) or a very LC diet ( $60 \%$ fat $/ 4 \%$ carbohydrate) for 1 y (34) reduced endothelium-dependent flow-mediated dilation of brachial arteries. A relatively very LC diet (60\% fat/ $20 \%$ carbohydrate) worsened the aortic augmentation index (35). These adverse effects might be mediated by a large amount of dietary fat. Therefore, a very LC diet was not recommended in the general population.

Mixed evidence that a mild LC diet (low-glycemic diet) decreases body weight in obese subjects

In a Cochrane review, a low-glycemic-index or lowglycemic load diet was compared with a high-glycemicindex or high-glycemic-load diet on different indices of body fat in 6 studies (36). Pooled data from 4 studies (37-40) showed that weight loss was significantly greater in participants $(n=163$ in total) receiving the low-glycemic diet $(-1.1 \mathrm{~kg}$ of difference, $p<0.05)$. Other studies reported a favorable percent change in body mass (41) or a favorable change in BMI on a lowglycemic diet $(39,42)$.

However, two recent intervention studies suggested that reduced-calorie diets resulted in meaningful weight loss, regardless of macronutrient balance. In one study, a total of 34 healthy overweight adults ate a high-glycemic load diet (20\% fat, $20 \%$ protein, and $60 \%$ carbohydrate) or a low-glycemic load diet $(30 \%$ fat, $30 \%$ protein, and $40 \%$ carbohydrate) under $30 \%$ energy-restricted conditions (43). There was no significant change in body weight between the two groups: percentage weight change at 12 mo was $-8.04 \pm 4.1 \%$ in the high-glycemic load diet group and $-7.81 \pm 5.0 \%$ in the low-glycemic load diet group. In the other study, a total of 811 overweight adults $\left(\mathrm{BMI}>25 \mathrm{~kg} / \mathrm{m}^{2}\right)$ ate one of four diets for $2 \mathrm{y}$ (44). The targeted percentages of energy derived from fat, protein, and carbohydrate in 
All

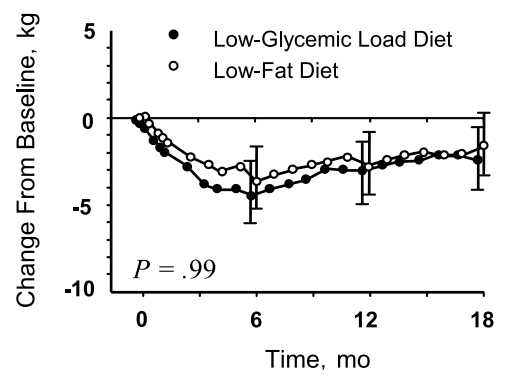

Insulin Concentration $<57.5 \mu \mathrm{lU} / \mathrm{mL}$ at 30 min After 75-g Dose of Oral Glucose
Insulin Concentration $>57.5 \mu \mathrm{IU} / \mathrm{mL}$ at 30 min After 75-g Dose of Oral Glucose
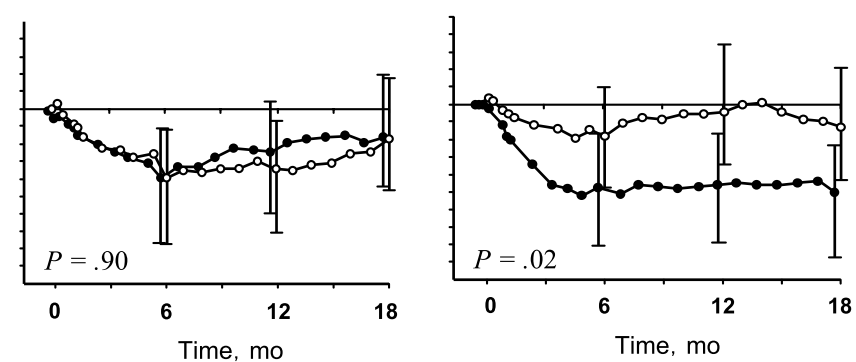

Fig. 2. Changes in body weight in insulin-sensitive and -resistant obese subjects. Obese nondiabetic insulin-sensitive (insulin concentration $\leq 57.5 \mu \mathrm{U} / \mathrm{mL}$ at $30 \mathrm{~min}$ after $75 \mathrm{-g}$ dose of oral glucose, $n=28$ ) and obese nondiabetic insulin-resistant (insulin concentration $>57.5 \mu \mathrm{U} / \mathrm{mL}$ at $30 \mathrm{~min}$ after $75 \mathrm{-g}$ dose of oral glucose, $n=28$ ) young adults were randomized to either a low-fat diet (55\% carbohydrate of energy, $20 \%$ fat, and $25 \%$ protein) or a low-glycemic load diet (or a low-carbohydrate diet; $40 \%$ carbohydrate, $35 \%$ fat, and $25 \%$ protein) for a 6 -mo intervention and a 12 -mo follow-up period. In the insulin-resistant groups, a low-glycemic load diet produced a greater decrease in weight than did the low-fat diet at 18 mo. Reproduced with permission (47).

the four diets were $20 \%, 15 \%$, and $65 \%$ (LF/low protein [LP] diet); $20 \%, 25 \%$, and $55 \%$ (LF/high protein [HP] diet); $40 \%, 15 \%$, and $45 \%$ (LC/LP diet); and $40 \%, 25 \%$, and $35 \%$ (LC/HP diet). At $2 \mathrm{y}$, weight loss remained similar in those who were assigned to a diet with $15 \%$ or $25 \%$ protein ( 3.0 and $3.6 \mathrm{~kg}$, respectively), in those assigned to a diet with $20 \%$ fat or $40 \%$ fat (3.3 kg for both groups), and in those assigned to a diet with $65 \%$ carbohydrate or $35 \%$ carbohydrate $(2.9$ and $3.4 \mathrm{~kg}$, respectively). There were no differences in reduction of body weights between groups when measured at 6,12 , and $18 \mathrm{mo}$. When considering the results of recent intervention studies, it is not conclusive that a mild LC diet is preferable for obese subjects.

A mild LC diet preferentially reduces body weights in obese subjects with hyperinsulinemia (insulin resistance)

The studies described above comprised mixed populations of insulin-sensitive and insulin-resistant obese subjects. However, when only the publications that separately examine the effects of LF and mild LC diets on body weight decrease in insulin-sensitive and insulinresistant subjects were selected, a clear picture appeared. In obese subjects with hyperinsulinemia and insulin resistance, a mild LC diet was more likely than was a LF diet to reduce body weight under energyrestricted conditions (45-47).

In the first intervention study, obese nondiabetic insulin-sensitive (fasting insulin $<10 \mu \mathrm{U} / \mathrm{mL}, n=12$ ) and obese nondiabetic insulin-resistant (fasting insulin $>15 \mu \mathrm{U} / \mathrm{mL}, n=9)$ women were randomized to either a LF diet (60\% carbohydrate, $20 \%$ fat, and $20 \%$ protein) or a mild LC diet ( $40 \%$ carbohydrate, $40 \%$ fat, and $20 \%$ protein) for $16 \mathrm{wk}$ under a 400-kcal energy deficit/d (45). A marked difference was observed in body weight reduction. Insulin-sensitive women on the LF diet lost $13.5 \pm 1.2 \%(n=6)$ of their initial body weight, whereas those on the mild LC diet lost $6.8 \pm 1.2 \%(n=6)$. In contrast, among the insulin-resistant women, those on the mild LC diet lost $13.4 \pm 1.3 \%(n=5)$ of their initial body weight as compared with $8.5 \pm 1.4 \%(n=4)$ lost by those on the LF diet. Differences in resting metabolic rate, physical activity, or energy intake between the two dietary groups were not observed (45).

In the second intervention study, obese (BMI 25$29.9 \mathrm{~kg} / \mathrm{m}^{2}$ ) insulin-sensitive (insulin concentration $\leq 66 \mu \mathrm{U} / \mathrm{mL}$ at $30 \mathrm{~min}$ after $75-\mathrm{g}$ dose of oral glucose, $n=16$ ) and obese nondiabetic insulin-resistant (insulin concentration $>66 \mu \mathrm{U} / \mathrm{mL}$ at $30 \mathrm{~min}$ after 75 -g dose of oral glucose, $n=16$ ) adults were randomized to either a LF diet (or high-glycemic diet; 60\% carbohydrate, $20 \%$ fat, and $20 \%$ protein) or a mild LC diet (or low-glycemic diet; $40 \%$ carbohydrate, $30 \%$ fat, and $30 \%$ protein) for 6 mo at 30\% calorie restriction compared to baseline individual energy needs (46). In the insulin-resistant groups, the mild LC diet produced a greater decrease in weight ( $-10.2 \mathrm{vs}-6.2 \mathrm{~kg}$ ) than did the LF diet at 6 mo. There were no significant differences in weight decrease between the mild LC and LF diets in the insulin-sensitive groups.

In the third intervention study, obese nondiabetic insulin-sensitive (insulin concentration $\leq 57.5 \mu \mathrm{U} / \mathrm{mL}$ at $30 \mathrm{~min}$ after $75 \mathrm{-g}$ dose of oral glucose, $n=28$ ) and obese nondiabetic insulin-resistant (insulin concentration $>57.5 \mu \mathrm{U} / \mathrm{mL}$ at $30 \mathrm{~min}$ after $75-\mathrm{g}$ dose of oral glucose, $n=28$ ) young adults were randomized to either a LF diet (or high-glycemic diet; 55\% carbohydrate, $20 \%$ fat, and $25 \%$ protein) or a mild LC diet (or low-glycemic diet; $40 \%$ carbohydrate, $35 \%$ fat, and $25 \%$ protein) for a 6-mo intervention and 12-mo follow-up period (47). Although both the mild LF- and LC-diet groups decreased energy intake similarly by $400 \mathrm{kcal} / \mathrm{d}$, effects of LF and LC diets on body weight reduction were markedly different between the insulin-sensitive and -resistant groups. In the insulin-resistant groups, the mild LC diet produced a greater decrease in weight $(-5.8 \mathrm{vs}$ $-1.2 \mathrm{~kg}$ ) and body fat percentage $(-2.6 \mathrm{vs}-0.9 \%)$ than did the LF diet at 18 mo (Fig. 2). There were no significant differences in decreases in weight and body 


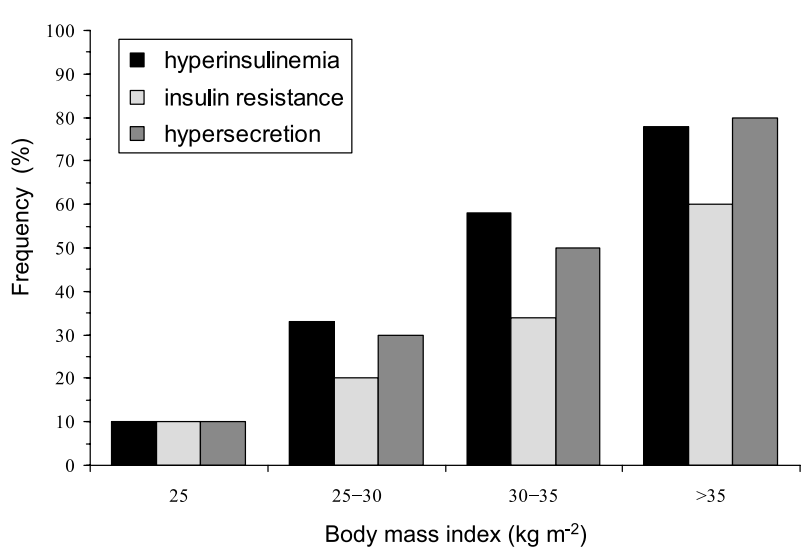

Fig. 3. Prevalence rates of insulin resistance, hyperinsulinemia, and insulin hypersecretion (all defined as the top decile of the respective distributions in lean subjects) as a function of the body mass index (BMI). Black bars, hyperinsulinemia; light gray bars, insulin resistance; dark gray bars, hypersecretion. Reproduced with permission (51).

fat between the mild LC and LF diets for any subjects or in the insulin-sensitive group.

Metabolic syndrome is closely associated with hyperinsulinemia (48). A recent study examining the effects of LF and mild LC diets in subjects with and without metabolic syndrome under 500-kcal/d energy deficit conditions indicated that a LF diet is preferable in insulin-sensitive obese subjects (49). In this study, 202 obese subjects were randomized to either a LF diet (55$60 \%$ carbohydrate, less than $30 \%$ fat, and $15 \%$ protein) or a mild LC diet (or low-glycemic diet; $30-35 \%$ carbohydrate, $35-40 \%$ fat, and $25-30 \%$ protein) for a $12-\mathrm{mo}$ follow-up period. In the subjects with metabolic syndrome, both the mild LC and LF diets were equally effective in reducing waist circumference, whereas in subjects without metabolic syndrome, the LF diet was preferable to that of the mild LC diet: the change in waist circumference was $-7.8 \pm 7.1 \mathrm{~cm}$ in the LF diet group versus $-3.8 \pm 5.0 \mathrm{~cm}$ in the mild LC diet group.

Thus, these four studies suggest that a mild LC diet preferentially reduces body weight in obese subjects with hyperinsulinemia (insulin resistance), whereas a LF diet preferentially reduces body weight in obese subjects without hyperinsulinemia.

Physiological aspects of a mild LC diet making it preferable in obese, insulin-resistant subjects to reduce body fat

It is known that not all obese subjects show insulin resistance $(50,51)$. In a European study of insulin resistance in the obese, hyperinsulinemia, insulin resistance, and insulin hypersecretion were found to increase linearly with an increase in BMI (Fig. 3) (51). In this study, hyperinsulinemia was defined as the upper $10 \%$ of fasting plasma insulin concentrations in the lean groups. Insulin resistance was defined as the bottom $10 \%$ of glucose disposal estimated by euglycemic insulin clamp technique in the lean groups, and insulin hypersecretion was defined as the upper $10 \%$ of the distribution of posthepatic insulin delivery rate.
According to these criteria, roughly one-half of the obese subjects (BMI $>30 \mathrm{~kg} / \mathrm{m}^{2}$ ) were insulin resistant. The frequency of insulin resistance was $20 \%$ in subjects with a BMI of $25-30 \mathrm{~kg} / \mathrm{m}^{2}, 34 \%$ in subjects with a BMI of $30-35 \mathrm{~kg} / \mathrm{m}^{2}$, and $60 \%$ in subjects with a BMI of $>35 \mathrm{~kg} / \mathrm{m}^{2}$, relative to $10 \%$ in subjects with a BMI of $25 \mathrm{~kg} / \mathrm{m}^{2}$ (51). Similar trends were observed in regard to hyperinsulinemia and insulin hypersecretion.

Insulin resistance in liver and skeletal muscles elevates glucose concentrations, by which insulin secretion is increased. Moreover, pancreatic beta cells can acutely assess the body's sensitivity to insulin and translate this information into an insulin response that is precisely balanced to offset the severity of insulin resistance (52). In patients with insulin resistance, the increment of insulin secretion from $\beta$-cells in response to a fixed amount of glucose is greater than that in normal subjects (53). Therefore, the sensitivity of glucose to an increased blood insulin level is augmented in obese subjects. Diets with higher glycemic load resulted in higher postprandial insulin concentration in a dosedependent manner in lean young adults (54). It is well known that obese subjects show hyperinsulinemia after oral glucose tolerance testing (glucose is a substance of high glycemic load) $(55,56)$. Postprandial hyperglycemia and hyperinsulinemia augmented by an increase in dietary carbohydrate intake in obese subjects may further promote fat cell enlargement (57).

Increased blood insulin stimulates the synthesis of fatty acid in liver and the preferential uptake of fatty acids in adipose tissues to store fat and prevents lipolysis in adipose tissues, all of which facilitate adipose tissue enlargement. Furthermore, these lipogenic effects of insulin are not impaired in obese subjects, whereas the glucose-lowering effects of insulin (inhibition of gluconeogenesis/glycolysis in the liver and stimulation of glucose uptake in skeletal muscles) is severely impaired. Recently, it was shown that hyperinsulinemia is associated with increased production of intestinal apoprotein B-48, which is one of the causes of postprandial hypertriglycemia (58). This effect of insulin also indirectly promotes obesity. In the following sections, the mechanisms of insulin-mediated increases in lipid synthesis and fat accumulation in the insulin-resistant state are reviewed.

Insulin-induced lipogenesis in liver is not impaired in insulin-resistant animals or humans

The insulin signaling pathway is thought to proceed through receptor-mediated tyrosine phosphorylation of insulin receptor substrate (IRS)-1 and/or IRS-2. This leads to activation of phosphoinositide 3-kinase (PI3K) and activated Akt (also known as protein kinase B). In activating hepatic lipogenesis, insulin increases transcription of genes encoding acetyl-CoA carboxylase, fatty acid synthase, and others. These actions are caused by an insulin-induced increase in sterol regulatory element-binding protein-1c (SREBP-1c) mRNA (59).

To examine the insulin signaling pathway and lipogenesis in the insulin-resistant state, two different ani- 
mal models of insulin resistance and hyperinsulinemia, those of lipodystrophy induced by overexpression of the aP2-SREBP1c transgene in adipocytes and obesity induced by mutational disruption of the leptin gene $(\mathrm{ob} /$ ob mice) were investigated (60). Both animal models showed a reduction of IRS- 2 mRNA and protein and increased gluconeogenesis in livers, whereas they showed an increase in SREBP-1c mRNA and lipogenesis. IRS-1 mRNA in the liver was not altered in these animal models. In addition, prolonged insulin treatment in isolated rat hepatocytes led to a fall in IRS-2 mRNA and protein and an increase in SREBP-1c transcript, suggesting that chronic hyperinsulinemia promotes gluconeogenesis in the liver and hyperglycemia, whereas it stimulates fatty acid synthesis in the liver and hypertriglycemia (60). It was shown with IRS-1 and IRS-2 liver knockout mice that IRS- 1 could convey signals to increase SREBP-1c mRNA and lipogenesis $(61,62)$. The complete blockage of insulin signaling observed in liver insulin receptor knockout mice showed a decrease in the expression of SREBP-1c (63), suggesting that selective insulin resistance may occur in animal models of insulin resistance (64). Recently, a branch point in the insulin signaling pathway that may account for selective insulin resistance (in which insulin loses its ability to block glucose production but retains its ability to stimulate lipogenesis) was identified (65). In rat hepatocytes, subnanomolar concentrations of rapamycin, an inhibitor of the mammalian target of rapamycin complex 1 (mTORC1), blocked insulin induction of SREBP-1c but had no effect on insulin suppression of phosphoenolpyruvate carboxylase (PEPCK), suggesting that the kinase complex designated mTORC1 was a branch point in the insulin signaling pathway. Therefore, the IRS-1/Akt/mTORC1 pathways are thought to mediate the increase of lipogenesis in the insulin-resistant state.

The finding that insulin-induced lipogenesis in the liver was not impaired in the insulin-resistant state in animal studies could apply to humans. The pattern of stored energy distribution derived from a high-carbohydrate meal is different in young, lean, insulin-resistant individuals (fasting insulin concentration of $12.1 \pm 1.2$ $\mu \mathrm{U} / \mathrm{mL}$ ) compared with young, lean, insulin-sensitive individuals (fasting insulin concentration of $7.6 \pm 0.6$ $\mu \mathrm{U} / \mathrm{mL}$ ) (66). In contrast to the insulin-sensitive subjects, who stored most of their ingested energy in the liver as glycogen, the insulin-resistant subjects had a marked defect in muscle glycogen synthesis and diverted much more of their ingested energy into hepatic de novo lipogenesis, as assessed by incorporation of deuterated water into plasma triglyceride, resulting in increased liver and plasma triglycerides (TGs). Increasing very-low-density lipoprotein-TG secretion from the liver may lead to increased fat accumulation in adipose tissue (67). Therefore, insulin activation of the liver IRS-1/Akt/mTORC1 pathway in the insulin-resistant state may lead to obesity.
An increase in lipoprotein lipase (LPL) activity in adipose tissue in response to insulin is not impaired in obese subjects

LPL, located on the capillary endothelium of tissues, catalyses the rate-limiting step in the hydrolysis of TGs from circulating chylomicrons and very-low-density lipoproteins. Most LPL is found in adipose tissues and skeletal muscles, where some of the liberated free fatty acids are taken up and are either stored or oxidized, respectively (68). In healthy humans, a combination of stable isotope labeling and arteriovenous difference measurements in adipose tissues showed that in postprandial periods, there is preferential uptake of fatty acids released from chylomicrons by LPL in adipose tissues and also a release of LPL-derived fatty acids into plasma (69). Therefore, an increase in LPL activity in adipose tissues may promote fat cell enlargement via increased uptake of fatty acids into adipocytes, in addition to an increased supply of fatty acids to muscle and liver.

Regulation of LPL activity is complex and is controlled by several modulators, such as apoproteins and angiopoietin-like proteins ANGPTL3 and ANGPTL4 (70). LPL is active as a dimer, whereas its monomer is inactive. ANGPTL4 inhibits LPL activity by promoting the conversion of active LPL dimers into inactive LPL monomers. Insulin not only increases the level of LPL mRNA but may also regulate LPL activity through both posttranscriptional and posttranslational mechanisms (71). The fact that feeding increases active dimeric LPL from inactive monomeric LPL in adipose tissues suggests that insulin may stimulate dimer formation of LPL by an unknown mechanism (72). Glucose also increases adipose tissue LPL activity and enhances the stimulatory effects of insulin, possibly by the glycosylation of LPL (73).

In humans, feeding or insulin/glucose infusion stimulates LPL activity in adipose tissues, whereas its activity decreases in skeletal muscles (74). This divergent response would serve to direct lipoprotein TG-derived fatty acids away from muscle to adipose tissue for storage. A high-carbohydrate diet for $16 \mathrm{~d}$ in normalweight subjects increased postprandial LPL activity in adipose tissue, with elevation of blood glucose and insulin concentrations after meals, relative to a high-fat diet (75). Therefore, increased insulin and glucose from a high-carbohydrate diet may promote obesity via activation of LPL in adipose tissues.

The LPL activity in adipose tissues in response to insulin during maintenance of euglycemia was examined in 22 obese and 8 normal-weight subjects (76). Basal levels of LPL activity per $g$ of fat tissue in the obese and control groups were $18.7 \pm 2.0$ and $9.6 \pm 2.7 \mathrm{nEq} /$ $\mathrm{g} / \mathrm{min}$, respectively. When the responses of LPL in absolute change from basal values were compared between the obese and control groups, no significant differences were found. However, because of the higher baseline LPL activity in the obese subjects, the percent increase in LPL from the basal value was significantly blunted in obese subjects. Basal LPL activity expressed per $10^{6}$ cells correlated positively with cell size, and both the 
obese and normal-weight subjects were found to respond similarly to insulin. These data suggest that insulin activates LPL in adipose tissues in obese subjects, irrespective of insulin resistance.

Inhibition of lipolysis in adipocytes in response to insulin is not impaired in insulin-resistant subjects

The concentration of blood free fatty acids (FFA) is determined primarily by their rate of appearance from adipose tissues (lipolysis) and also by their rate of disappearance from plasma. Blood FFA concentrations are elevated during fasting and decreased after feeding. Lipolysis is stimulated by catecholamines during fasting and inhibited by insulin after feeding. If the antilipolytic effect of insulin in obese subjects were impaired due to insulin resistance, fat mass would be smaller in obese subjects. However, most of the studies suggested that insulin resistance is not observed at this step in obese subjects (see following paragraph), although the resistance of insulin to increased glucose oxidation in enlarged adipocytes was clearly shown and is due to a marked decrease in GLUT4 in adipocytes $(77,78)$.

The antilipolytic effects of insulin on fat cells of different sizes were examined in the 1970s by measuring glycerol release. Basal lipolysis was larger in larger cells (79). The antilipolytic effects of insulin on noradrenalin-stimulated lipolysis were more pronounced in the large cells at all tested concentrations $(80,81)$. Responsiveness and sensitivity to insulin was not altered in adipose tissues of either control or obese subjects (82). Rather, a marked resistance to the lipolytic effect of noradrenalin was observed in isolated adipocytes from obese subjects (83).

In vivo studies also show that the antilipolytic effect of insulin is not impaired in obese subjects. Both antilipolytic and antiketotic actions occurred at lower insulin concentrations $(<90 \mu \mathrm{U} / \mathrm{mL})$ than those required for hypoglycemic activity $(>1,000 \mu \mathrm{U} / \mathrm{mL})(84)$, suggesting that marked insulin resistance might be required to reduce antilipolytic action in adipose tissues. Decreases in blood FFA and glycerol observed during oral glucose tolerance tests were not impaired in obese subjects (85). Insulin and glucose infusion rapidly produced antilipolysis in obese and normal groups, as evidenced by large falls in FFA at 20 min after insulin infusion, where FFA was $47 \%$ of the basal level in the obese subjects and $31 \%$ of the basal level in the normal subjects (76).

Triglycerides in tissues are hydrolyzed in a sequential process involving different lipases. Adipose triglyceride lipase (ATGL) and hormone-sensitive lipase (HSL) are necessary for proper hydrolysis of tri- and diglycerides, respectively. The last step in lipolysis is performed by monoglyceride lipase (MGL), which hydrolyzes monoglycerides to form glycerol and fatty acids (86). The activity of ATGL and HSL is tightly regulated by catecholamines and insulin. $\beta$-Adrenergic stimulation of the G-protein-coupled receptor activates adenylate cyclase to increase cellular cAMP levels. The antilipolytic action of insulin is mediated by lowering cAMP levels via activation of phosphodiesterase 3B (87). The IRS-1/ PI3K/PDE3IK (an insulin-stimulated protein serine
Hyperinsulinemia (or obesity)

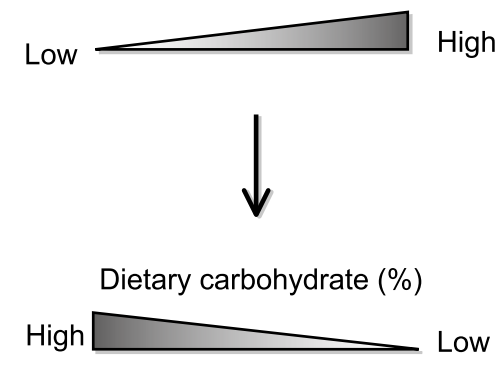

Dietary fat $(\%)$

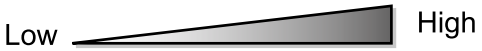

Fig. 4. A proposed model of optimal dietary fat to carbohydrate ratio according to the degree of hyperinsulinemia (or obesity). A key to macronutrient balance in the reduction of body weight is the state of hyperinsulinemia (insulin resistance or obesity); thus, optimal dietary fat to carbohydrate ratios may differ between prevention and treatment of obesity. A mild low-carbohydrate diet ( $40 \%$ carbohydrate) is preferable for obese, hyperinsulinemic, insulin-resistant subjects, whereas a low-fat diet $(20-25 \%$ fat $)$ is preferable for normalweight, normoinsulinemic, insulin-sensitive subjects.

kinase) signaling pathway is involved in PDE3B activation (88). cAMP binding to protein kinase A (PKA) induces phosphorylation of HSL and perilipin, a protein coating the lipid droplet. PKA phosphorylation of HSL causes HSL translocation from the cytosol to the lipid droplet, whereas phosphorylation of perilipin by PKA alleviates the barrier function of this protein and promotes lipolysis (89). ATGL is phosphorylated on two conserved serine residues (Ser 404 and 428), although PKA does not phosphorylate ATGL (90). However, insulin treatment downregulates ATGL mRNA levels in adipocytes $(91,92)$. To my knowledge, it has not been shown that decreases in cAMP concentration or ATGL mRNA in adipocytes in response to insulin are blunted in adipocytes from obese subjects.

Shift from a mild LC diet to a LF diet during obesity treatment (hypothesis)

When a mild LC diet is given to obese subjects, body weights might decrease with improvement in hyperinsulinemia and insulin resistance. Data from the National Weight Control Registry of people who were successful in losing weight and maintaining reduced body weight show that despite wide variation in the methods used to lose body weight, there was remarkable similarity in how they maintained the weight loss, including a diet that was, on average, $24 \%$ fat (93). Therefore, fat intake might be gradually decreased with a concomitant increase in carbohydrate intake with improvement in obesity (Fig. 4).

\section{Conclusions}

In terms of epidemiological, physiological, and molecular aspects, the optimal dietary fat to carbohydrate ratio varies due to the amount of body fat present and 
to hyperinsulinemia (insulin resistance). No evidence was found that the lipogenic effects of insulin were impaired in subjects with insulin resistance. In general, in non-obese subjects, most of whom are insulin sensitive, decreasing fat intake is more effective than decreasing carbohydrates to prevent obesity. However, for obese subjects with insulin resistance, a mild LC diet favors a reduction in body weight. The optimal dietary fat to carbohydrate ratio may differ depending on whether the goal is prevention or treatment of obesity, and public guidelines on macronutrients should either be based on the prevalence of obesity in the target society or individualized.

\section{Acknowledgments}

This work was supported by research grants from the Japanese Ministry of Health, Labor and Welfare (Tokyo, Japan).

\section{REFERENCES}

1) Flegal KM, Carroll MD, Ogden CL, Johnson CL. 2002. Prevalence and trends in obesity among US adults, 1999-2000. JAMA 288: 1723-1727.

2) Hu FB, Manson JE, Stampfer MJ, Colditz G, Liu S, Solomon CG, Willett WC. 2001. Diet, lifestyle, and the risk of type 2 diabetes mellitus in women. $N$ Engl J Med 345: 790-797.

3) Ministry of Health, Labour, and Welfare. 2010. The National Health and Nutrition Survey in Japan, 2007. Tokyo (in Japanese).

4) Nagaya T, Yoshida H, Takahashi H, Kawai M. 2005. Increases in body mass index, even within non-obese levels, raise the risk for Type 2 diabetes mellitus: a follow-up study in a Japanese population. Diabet Med 22: 1107-1111.

5) Bantle JP, Wylie-Rosett J, Albright AL, Apovian CM, Clark NG, Franz MJ, Hoogwerf BJ, Lichtenstein AH, Mayer-Davis E, Mooradian AD, Wheeler ML. 2006. Nutrition recommendations and interventions for diabetes-2006: a position statement of the American Diabetes Association. Diabetes Care 29: 2140-2157.

6) Kush LH, Byers T, Doyle C, Bandera EV, McCullough M, McTiernan A, Gansler T, Andrews KS, Thun MJ. 2006. American Cancer Society Guidelines on Nutrition and Physical Activity for cancer prevention: reducing the risk of cancer with healthy food choices and physical activity. CA Cancer J Clin 56: 254-281.

7) Lichtenstein AH, Appel LJ, Brands M, Carnethon M, Daniels S, Franch HA, Franklin B, Kris-Etherton P, Harris WS, Howard B, Karanja N, Lefevre M, Rudel L, Sacks F, Van Horn L, Winston M, Wylie-Rosett J. 2006. Diet and lifestyle recommendations revision 2006: a scientific statement from the American Heart Association Nutrition Committee. Circulation 114: 82-96.

8) Food and Nutrition Board, Institute of Medicine. 2005. Macronutrients and healthful diets. In: Dietary Reference Intakes for Energy, Carbohydrate, Fiber, Fat, Fatty Acids, Cholesterol, Protein, and Amino Acids, p 769879. National Academy Press, Washington DC.

9) Freedman MR, King J, Kennedy E. 2001. Popular diets: a scientific review. Obes Res 9 (Suppl 1): 1S-40S.

10) Astrup A, Ryan L, Grunwald GK, Storgaard M, Saris W, Melanson E, Hill JO. 2000. The role of dietary fat in body fatness: evidence from a preliminary meta-analysis of ad libitum low-fat dietary intervention studies. Br J Nutr 83 (Suppl 1): S25-32.

11) Yu-Poth $S$, Zhao G, Etherton T, Naglak M, Jonnalagadda S, Kris-Etherton PM. 1999. Effects of the National Cholesterol Education Program's Step I and Step II dietary intervention programs on cardiovascular disease risk factors: a meta-analysis. Am J Clin Nutr 69: 632-646.

12) Howard BV, Manson JE, Stefanick ML, Beresford SA, Frank G, Jones B, Rodabough RJ, Snetselaar L, Thomson C, Tinker L, Vitolins M, Prentice R. 2006. Low-fat dietary pattern and weight change over 7 years: the Women's Health Initiative Dietary Modification Trial. JAMA 295: 39-49.

13) Pi-Sunyer FX. 1990. Effect of the composition of the diet on energy intake. Nutr Rev 48: 94-105.

14) Gershoff SN. 1995. Nutrition evaluation of dietary fat substitutes. Nutr Rev 53: 305-313.

15) Donato K, Hegsted DM. 1985. Efficiency of utilization of various sources of energy for growth. Proc Natl Acad Sci USA 82: 4866-4870.

16) Astrup A. 1993. Dietary composition, substrate balances and body fat in subjects with a predisposition to obesity. Int J Obes Relat Metab Disord 17 (Suppl 3): S3236.

17) Flatt JP. 1995. McCollum Award Lecture, 1995: diet, lifestyle, and weight maintenance. Am J Clin Nutr 62: 820-836.

18) Flatt JP, Ravussin E, Acheson KJ, Jequier E. 1985. Effects of dietary fat on postprandial substrate oxidation and on carbohydrate and fat balances. J Clin Invest 76: 10191024.

19) Dansinger ML, Schaefer EJ. 2006. Low-carbohydrate or low-fat diets for the metabolic syndrome? Curr Diab Rep 6: 55-63.

20) de Souza RJ, Swain JF, Appel LJ, Sacks FM. 2008. Alternatives for macronutrient intake and chronic disease: a comparison of the OmniHeart diets with popular diets and with dietary recommendations. Am J Clin Nutr $\mathbf{8 8}$ : $1-11$.

21) Hession M, Rolland C, Kulkarni U, Wise A, Broom J. 2009. Systematic review of randomized controlled trials of low-carbohydrate vs. low-fat/low-calorie diets in the management of obesity and its comorbidities. Obes Rev 10: $36-50$.

22) Nordmann AJ, Nordmann A, Briel M, Keller U, Yancy WS Jr, Brehm BJ, Bucher HC. 2006. Effects of low-carbohydrate vs low-fat diets on weight loss and cardiovascular risk factors: a meta-analysis of randomized controlled trials. Arch Intern Med 166: 285-293.

23) Brehm BJ, Seeley RJ, Daniels SR, D’Alessio DA. 2003. A randomized trial comparing a very low carbohydrate diet and a calorie-restricted low fat diet on body weight and cardiovascular risk factors in healthy women. J Clin Endocrinol Metab 88: 1617-1623.

24) Due A, Toubro S, Skov AR, Astrup A. 2004. Effect of normal-fat diets, either medium or high in protein, on body weight in overweight subjects: a randomised 1year trial. Int J Obes Relat Metab Disord 28: 1283-1290.

25) Foster GD, Wyatt HR, Hill JO, McGuckin BG, Brill C, Mohammed BS, Szapary PO, Rader DJ, Edman JS, Klein S. 2003. A randomized trial of a low-carbohydrate diet for obesity. N Engl J Med 348: 2082-2090.

26) Samaha FF, Iqbal N, Seshadri P, Chicano KL, Daily DA, McGrory J. Williams T, Williams M, Gracely EJ, Stern L. 
2003. A low-carbohydrate as compared with a low-fat diet in severe obesity. N Engl J Med 348: 2074-2081.

27) Seshadri P, Iqbal, N, Stern L, Williams M, Chicano KL, Daily DA, McGrory J, Gracely EJ, Rader DJ, Samaha FE. 2004. A randomized study comparing the effects of a low-carbohydrate diet and a conventional diet on lipoprotein subfractions and C-reactive protein levels in patients with severe obesity. Am J Med 117: 398-405.

28) Yancy WS Jr, Olsen MK, Guyton JR, Bakst RP, Westman EC. 2004. A low-carbohydrate, ketogenic diet versus a low-fat diet to treat obesity and hyperlipidemia: a randomized, controlled trial. Ann Intern Med 140: 769777.

29) Brinkworth GD, Noakes M, Keogh JB, Luscombe ND, Wittert GA, Clifton PM. 2004. Long-term effects of a high-protein, low-carbohydrate diet on weight control and cardiovascular risk markers in obese hyperinsulinemic subjects. Int J Obes Relat Metab Disord 28: 661-670.

30) Dansinger ML, Gleason JA, Griffith JL, Selker HP, Schaefer EJ. 2005. Comparison of the Atkins, Ornish, Weight Watchers, and Zone diets for weight loss and heart disease risk reduction: a randomized trial. JAMA 293: 43-53.

31) Truby H, Baic S, deLooy A, Fox KR, Livingstone MB, Logan CM, Macdonald IA, Morgan LM, Taylor MA, Millward DJ. 2006. Randomised controlled trial of four commercial weight loss programmes in the UK: initial findings from the BBC "diet trials." BMJ 332: 13091314.

32) Larosa JC, Fry AG, Muesing R, Rosing DR. 1980. Effects of high-protein, low-carbohydrate dieting on plasma lipoproteins and body weight. J Am Diet Assoc 77: 264270.

33) Varady KA, Bhutani S, Klempel MC, Phillips SA. 2011. Improvements in vascular health by a low-fat diet, but not a high-fat diet, are mediated by changes in adipocyte biology. Nutr J 10: 18.

34) Wycherley TP, Brinkworth GD, Keogh JB, Noakes M, Buckley JD, Clifton PM. 2010. Long-term effects of weight loss with a very low carbohydrate and low fat diet on vascular function in overweight and obese patients. J Intern Med 267: 452-461.

35) Bradley U, Spence M, Courtney CH, McKinley MC, Ennis CN, McCance DR, McEneny J, Bell PM, Young IS, Hunter SJ. 2009. Low-fat versus low-carbohydrate weight reduction diets: effects on weight loss, insulin resistance, and cardiovascular risk: a randomized control trial. Diabetes 58: 2741-2748.

36) Thomas DE, Elliott EJ, Baur L. 2007. Low glycaemic index or low glycaemic load diets for overweight and obesity. Cochrane Database Syst Rev 18: CD005105.

37) Bouche C, Rizkalla SW, Luo J, Vidal H, Veronese A, Pacher N, Fouquet C, Lang V, Slama G. 2002. Fiveweek, low-glycemic index diet decreases total fat mass and improves plasma lipid profile in moderately overweight nondiabetic men. Diabetes Care 25: 822-828.

38) McMillan-Price J, Petocz P, Atkinson F, O'Neill K, Samman S, Steinbeck K, Caterson I, Brand-Miller J. 2006. Comparison of 4 diets of varying glycemic load on weight loss and cardiovascular risk reduction in overweight and obese young adults: a randomized controlled trial. Arch Intern Med 166: 1466-1475.

39) Slabber M, Barnard HC, Kuyl JM, Dannhauser A, Schall R. 1994. Effects of a low-insulin-response, energyrestricted diet on weight loss and plasma insulin con- centrations in hyperinsulinemic obese females. Am I Clin Nutr 60: 48-53.

40) Sloth B, Krog-Mikkelsen I, Flint A, Tetens I, Bjorck I, Vinoy S, Elmstahl H, Astrup A, Lang V, Raben A. 2004. No difference in body weight decrease between a lowglycemic-index and a high-glycemic-index diet but reduced LDL cholesterol after 10-wk ad libitum intake of the low-glycemic-index diet. Am J Clin Nutr 80: $337-$ 347.

41) Ebbeling CB, Leidig MM, Sinclair KB, Seger-Shippee LG, Feldman HA, Ludwig DS. 2005. Effects of an ad libitum low-glycemic load diet on cardiovascular disease risk factors in obese young adults. Am J Clin Nutr 81: 976982.

42) Ebbeling CB, Leidig MM, Sinclair KB, Hangen JP, Ludwig DS. 2003. A reduced-glycemic load diet in the treatment of adolescent obesity. Arch Pediatr Adolesc Med 157: $773-779$.

43) Das SK, Gilhooly CH, Golden JK, Pittas AG, Fuss PJ, Cheatham RA, Tyler S, Tsay M, McCrory MA, Lichtenstein AH, Dallal GE, Dutta C, Bhapkar MV, Delany JP, Saltzman E, Roberts SB. 2007. Long-term effects of 2 energy-restricted diets differing in glycemic load on dietary adherence, body composition, and metabolism in CALERIE: a 1-y randomized controlled trial. Am J Clin Nutr 85: 1023-1030.

44) Sacks FM, Bray GA, Carey VJ, Smith SR, Ryan DH, Anton SD, McManus K, Champagne CM, Bishop LM, Laranjo N, Leboff MS, Rood JC, de Jonge L, Greenway FL, Loria CM, Obarzanek E, Williamson DA. 2009. Comparison of weight-loss diets with different compositions of fat, protein, and carbohydrates. N Engl J Med 360: 859873.

45) Cornier MA, Donahoo WT, Pereira R, Gurevich I, Westergren R, Enerback S, Eckel PJ, Goalstone ML, Hill JO, Eckel RH, Draznin B. 2005. Insulin sensitivity determines the effectiveness of dietary macronutrient composition on weight loss in obese women. Obes Res 13: 703-709.

46) Pittas AG, Das SK, Hajduk CL, Golden J, Saltzman E, Stark PC, Greenberg AS, Roberts SB. 2005. A low-glycemic load diet facilitates greater weight loss in overweight adults with high insulin secretion but not in overweight adults with low insulin secretion in the CALERIE Trial. Diabetes Care 28: 2939-2941.

47) Ebbeling CB, Leidig MM, Feldman HA, Lovesky MM, Ludwig DS. 2007. Effects of a low-glycemic load vs lowfat diet in obese young adults: a randomized trial. JAMA 297: 2092-2102.

48) DeFronzo RA, Ferrannini E. 1991. Insulin resistance. A multifaceted syndrome responsible for NIDDM, obesity, hypertension, dyslipidemia, and atherosclerotic cardiovascular disease. Diabetes Care 14: 173-194.

49) Klemsdal TO, Holme I, Nerland H, Pedersen TR, Tonstad S. 2010. Effects of a low glycemic load diet versus a lowfat diet in subjects with and without the metabolic syndrome. Nutr Metab Cardiovasc Dis 20: 195-201.

50) Brochu M, Tchernof A, Dionne IJ, Sites CK, Eltabbakh GH, Sims EA, Poehlman ET. 2001. What are the physical characteristics associated with a normal metabolic profile despite a high level of obesity in postmenopausal women? J Clin Endocrinol Metab 86: 1020-1025.

51) Ferrannini E, Natali A, Bell P, Cavallo-Perin P, Lalic N, Mingrone G. 1997. Insulin resistance and hypersecretion in obesity. European Group for the Study of Insulin 
Resistance (EGIR). J Clin Invest 100: 1166-1173.

52) Diamond MP, Thornton K, Connolly-Diamond M, Sherwin RS, DeFronzo RA. 1995. Reciprocal variations in insulin-stimulated glucose uptake and pancreatic insulin secretion in women with normal glucose tolerance. J Soc Gynecol Investig 2: 708-715.

53) Defronzo RA. 2009. Banting Lecture. From the triumvirate to the ominous octet: a new paradigm for the treatment of type 2 diabetes mellitus. Diabetes 58: 773-795.

54) Brand-Miller JC, Thomas M, Swan V, Ahmad ZI, Petocz P, Colagiuri S. 2003. Physiological validation of the concept of glycemic load in lean young adults. J Nutr 133: 2728-2732.

55) Perley MJ, Kipnis DM. 1967. Plasma insulin responses to oral and intravenous glucose: studies in normal and diabetic subjects. J Clin Invest 46: 1954-1962.

56) Le Stunff C, Bougneres P. 1994. Early changes in postprandial insulin secretion, not in insulin sensitivity, characterize juvenile obesity. Diabetes 43: 696-702.

57) Brand-Miller JC, Holt SH, Pawlak DB, McMillan J. 2002. Glycemic index and obesity. Am J Clin Nutr 76: 281S285S.

58) Duez H, Pavlic M, Lewis GF. 2008. Mechanism of intestinal lipoprotein overproduction in insulin resistant humans. Atheroscler Suppl 9: 33-38.

59) Horton JD, Goldstein JL, Brown MS. 2002. SREBPs: activators of the complete program of cholesterol and fatty acid synthesis in the liver. J Clin Invest 109: 11251131.

60) Shimomura I, Matsuda M, Hammer RE, Bashmakov Y, Brown MS, Goldstein JL. 2000. Decreased IRS-2 and increased SREBP-1c lead to mixed insulin resistance and sensitivity in livers of lipodystrophic and ob/ob mice. Mol Cell 6: 77-86.

61) Kubota N, Kubota $\mathrm{T}$, Itoh $\mathrm{S}$, Kumagai $\mathrm{H}$, Kozono $\mathrm{H}$, Takamoto I, Mineyama T, Ogata H, Tokuyama K, Ohsugi M, Sasako T, Moroi M, Sugi K, Kakuta S, Iwakura Y, Noda T, Ohnishi S, Nagai R, Tobe K, Terauchi Y, Ueki K, Kadowaki T. 2008. Dynamic functional relay between insulin receptor substrate 1 and 2 in hepatic insulin signaling during fasting and feeding. Cell Metab 8: $49-64$.

62) Guo S, Copps KD, Dong X, Park S, Cheng Z, Pocai A, Rossetti L, Sajan M, Farese RV, White MF. 2009. The Irs1 branch of the insulin signaling cascade plays a dominant role in hepatic nutrient homeostasis. Mol Cell Biol 29: 5070-5083.

63) Biddinger SB, Hernandez-Ono A, Rask-Madsen C, Haas JT, Aleman JO, Suzuki R, Scapa EF, Agarwal C, Carey MC, Stephanopoulos G, Cohen DE, King GL, Ginsberg HN, Kahn CR. 2008. Hepatic insulin resistance is sufficient to produce dyslipidemia and susceptibility to atherosclerosis. Cell Metab 7: 125-134.

64) Brown MS, Goldstein JL. 2008. Selective versus total insulin resistance: a pathogenic paradox. Cell Metab 7: 95-96.

65) Li S, Brown, MS, Goldstein JL. 2010. Bifurcation of insulin signaling pathway in rat liver: $\mathrm{mTORC} 1$ required for stimulation of lipogenesis, but not inhibition of gluconeogenesis. Proc Natl Acad Sci USA 107: 3441-3446.

66) Petersen KF, Dufour S, Savage DB, Bilz S, Solomon G, Yonemitsu S, Cline GW, Befroy D, Zemany L, Kahn BB, Papademetris X, Rothman DL, Shulman GI. 2007. The role of skeletal muscle insulin resistance in the pathogenesis of the metabolic syndrome. Proc Natl Acad Sci
USA 104: 12587-12594.

67) Yamazaki T, Sasaki E, Kakinuma C, Yano T, Miura S, Ezaki O. 2005. Increased very low density lipoprotein secretion and gonadal fat mass in mice overexpressing liver DGAT1. J Biol Chem 280: 21506-21514.

68) Goldberg IJ. 1996. Lipoprotein lipase and lipolysis: central roles in lipoprotein metabolism and atherogenesis. $J$ Lipid Res 37: 693-707.

69) Bickerton AS, Roberts R, Fielding BA, Hodson L, Blaak EE, Wagenmakers AJ, Gilbert M, Karpe F, Frayn KN. 2007. Preferential uptake of dietary fatty acids in adipose tissue and muscle in the postprandial period. Diabetes 56: 168-176.

70) Lichtenstein L, Kersten S. 2010. Modulation of plasma TG lipolysis by angiopoietin-like proteins and GPIHBP1. Biochim Biophys Acta 1801: 415-420.

71) Wang H, Eckel RH. 2009. Lipoprotein lipase: from gene to obesity. Am J Physiol Endocrinol Metab 297: E271288.

72) Bergo M, Olivecrona G, Olivecrona T. 1996. Forms of lipoprotein lipase in rat tissues: in adipose tissue the proportion of inactive lipase increases on fasting. Biochem J 313 (Pt 3): 893-898.

73) Ong JM, Kern PA. 1989. The role of glucose and glycosylation in the regulation of lipoprotein lipase synthesis and secretion in rat adipocytes. J Biol Chem 264: 31773182.

74) Farese RV Jr, Yost TJ, Eckel RH. 1991. Tissue-specific regulation of lipoprotein lipase activity by insulin/glucose in normal-weight humans. Metabolism 40: 214216.

75) Yost TJ, Jensen DR, Haugen BR, Eckel RH. 1998. Effect of dietary macronutrient composition on tissue-specific lipoprotein lipase activity and insulin action in normalweight subjects. Am J Clin Nutr 68: 296-302.

76) Sadur CN, Yost TJ, Eckel RH. 1984. Insulin responsiveness of adipose tissue lipoprotein lipase is delayed but preserved in obesity. J Clin Endocrinol Metab 59: 11761182.

77) Ezaki O, Fukuda N, Itakura H. 1990. Role of two types of glucose transporters in enlarged adipocytes from aged obese rats. Diabetes 39: 1543-1549.

78) Ezaki O, Tsuji E, Momomura K, Kasuga M, Itakura H. 1992. Effects of fish and safflower oil feeding on subcellular glucose transporter distributions in rat adipocytes. Am J Physiol 263: E94-101.

79) Jacobsson B, Smith U. 1972. Effect of cell size on lipolysis and antilipolytic action of insulin in human fat cells. J Lipid Res 13: 651-656.

80) Jacobsson B, Holm G, Bjorntorp P, Smith U. 1976. Influence of cell size on the effects of insulin and noradrenaline on human adipose tissue. Diabetologia 12: 69-72.

81) Ostman J, Backman L, Hallberg D. 1975. Cell size and the antilipolytic effect of insulin in human subcutaneous adipose tissue. Diabetologia 11: 159-164.

82) Arner P, Bolinder J, Engfeldt P, Ostman J. 1981. The antilipolytic effect of insulin in human adipose tissue in obesity, diabetes mellitus, hyperinsulinemia, and starvation. Metabolism 30: 753-760.

83) Reynisdottir S, Ellerfeldt K, Wahrenberg H, Lithell H, Arner P. 1994. Multiple lipolysis defects in the insulin resistance (metabolic) syndrome. J Clin Invest 93: 2590-2599.

84) Schade DS, Eaton RP. 1977. Dose response to insulin in man: differential effects on glucose and ketone body 
regulation. J Clin Endocrinol Metab 44: 1038-1053.

85) Howard BV, Savage PJ, Nagulesparan M, Bennion LJ, Unger RH, Bennett PH. 1979. Evidence for marked sensitivity to the antilipolytic action of insulin in obese maturity-onset diabetics. Metabolism 28: 744-750.

86) Zimmermann R, Lass A, Haemmerle G, Zechner R. 2009. Fate of fat: the role of adipose triglyceride lipase in lipolysis. Biochim Biophys Acta 1791: 494-500.

87) Shakur Y, Holst LS, Landstrom TR, Movsesian M, Degerman E, Manganiello V. 2001. Regulation and function of the cyclic nucleotide phosphodiesterase (PDE3) gene family. Prog Nucleic Acid Res Mol Biol 66: 241-277.

88) Degerman E, Belfrage P, Manganiello VC. 1997. Structure, localization, and regulation of cGMP-inhibited phosphodiesterase (PDE3). J Biol Chem 272: 68236826.

89) Holm C. 2003. Molecular mechanisms regulating hormone-sensitive lipase and lipolysis. Biochem Soc Trans 31: 1120-1124.

90) Zimmermann R, Strauss JG, Haemmerle G, Schoiswohl
G, Birner-Gruenberger R, Riederer M, Lass A, Neuberger G, Eisenhaber F, Hermetter A, Zechner R. 2004. Fat mobilization in adipose tissue is promoted by adipose triglyceride lipase. Science 306: 1383-1386.

91) Kim JY, Tillison K, Lee JH, Rearick DA, Smas CM. 2006. The adipose tissue triglyceride lipase ATGL/PNPLA2 is downregulated by insulin and TNF-alpha in 3T3L1 adipocytes and is a target for transactivation by PPARgamma. Am J Physiol Endocrinol Metab 291: E115-127.

92) Kralisch S, Klein J, Lossner U, Bluher M, Paschke R, Stumvoll M, Fasshauer M. 2005. Isoproterenol, TNFalpha, and insulin downregulate adipose triglyceride lipase in 3T3-L1 adipocytes. Mol Cell Endocrinol 240: 43-49.

93) Klem ML, Wing RR, McGuire MT, Seagle HM, Hill JO. 1997. A descriptive study of individuals successful at long-term maintenance of substantial weight loss. Am J Clin Nutr 66: 239-246. 